\title{
Development and Validation of the Entrepreneurial Opinions Scale among the Cameroonian Self-Made Men and Women
}

\author{
S. Nyock Ilouga1 ${ }^{1}$ A. C. Moussa Mouloungui ${ }^{2}$, Adalgisa Battistelli3 ${ }^{3}$ \\ ${ }^{1}$ Psychology, Yaounde 1 University, Yaoundé, Cameroon \\ ${ }^{2}$ Psychology, Omar Bongo University, Libreville, Gabon \\ ${ }^{3}$ Psychology, University of Bordeaux, Bordeaux, France \\ Email: Nyock.ilouga@gmail.com
}

How to cite this paper: Nyock Ilouga, S., Moussa Mouloungui, A. C., \& Battistelli, A. (2020). Development and Validation of the Entrepreneurial Opinions Scale among the Cameroonian Self-Made Men and Women. Sociology Mind, 10, 127-148.

https://doi.org/10.4236/sm.2020.103009

Received: February 3, 2020

Accepted: May 12, 2020

Published: May 15, 2020

Copyright (c) 2020 by author(s) and Scientific Research Publishing Inc. This work is licensed under the Creative Commons Attribution International License (CC BY 4.0).

http://creativecommons.org/licenses/by/4.0/

\begin{abstract}
The lack of validated evaluation tools on African continent is detrimental to the development of action research, particularly in entrepreneurship. The challenge is to reinforce existing mechanisms that can promote entrepreneurial behavior and at the same time capture the personal dynamics involved in transforming entrepreneurial intention into action. The purpose of this study is to develop and validate measurement tools to evaluate the opinions of Cameroonians in the face of entrepreneurship and entrepreneurial occupation. The results, obtained from a sample of 2552 students, self-made men and women, revealed a three-dimensional scale (factor 1: Benefactor, $36.68 \%$ of the variance; factor 2: Commitment and capacities, $25.7 \%$ of the variance; factor 3 : availing, $16.64 \%$ variance) whose internal validity (.89) and the stability of the factor structure ensure good psychometric qualities to the tools.
\end{abstract}

\section{Keywords}

Opinions, Entrepreneurship, Intention, Actions

\section{Introduction}

Self-employment which falls under informal sector, is increasingly being imposed on African youths as the only alternative to counter the prospect of unemployment in an entropic environment marked by pauperism and the collapse of the value given to work (Mercure \& Vultur, 2010). The production, processing, marketing, repair or service delivery entities that arise from men and 
women creativity and which are motivated by the desire to quit unemployment, have its main function of providing jobs and livelihoods to their promoters and are part of relational and transactional processes in favor of the formal economy. However, we do not have validated tools within the African continent to assess the opinions of these self-made men regarding entrepreneurship. This situation is detrimental to the development of training programs designed to stimulate entrepreneurship and innovation. Since governments have given a go-ahead to private institutions in the informal sector (Peris-Ortiz et al., 2017), the challenge now is to consolidate that sector by putting in place an organization that guarantees the social protection of workers and provides funding for activities in order to structure and transform this sector into a source of wealth for fragile economies. This process will result in the transformation of small family entities into the formal economy, arising from resourcefulness, without social protection and exempt from tax charges. It seems obvious that such transformation is only possible with the involvement of informal sectors operators, who are apparently not in favor of any change having regard to fiscal and administrative constraints that such an operation is likely to generate. Taking into account their opinion coupled with the legalization of their activities, can help assess the chances of success of such a transformation, essential for the continent's faltering economy (Krueger \& Carsrud, 1993). Supported by international institutions (IMF, World Bank), Cameroon, like other African countries, is multiplying incentive programs for the creation of businesses which, in the absence of adequate project evaluation, do not produce expected results. Data published by the Cameroonian Institute of Statistics revealed that about $4 \%$ of the working-age population works in the formal private sector. The public sector employs $5 \%$ in the government and $1 \%$ in public enterprises. The others (about 90\%) are doing well in the informal sector with a sectorial breakdown of $53 \%$ in the informal tertiary sector and $37 \%$ in informal agricultural sector. The study carried out by the Center for Analysis on Social and Economic Policy in Cameroon (Camercap, 2015) revealed a significant increase in the number of creation of fictitious enterprises, but with low survival rates. Clarifying in our article the opinions of young people regarding self-employment in general and entrepreneurship in particular, the aim is to capture the dynamics that are at the start of the business creation. Seen as predicting entrepreneurial intention, opinions play a decisive role in the process of transforming intentions into action (Moussa Mouloungui, 2012). The ultimate goal of this work is to proceed with the validation of the scale of opinions on entrepreneurship by clarifying its role in formulating entrepreneurship intention.

\section{Context}

The study of the entrepreneurship process is presented with a new acuteness for workers who are working in an entropic context, marked by the collapse of the value given to work (Mercure \& Vultur, 2010), with as corollaries boredom, dis- 
sipation, emptiness, apathy and dishonest conducts. These conducts are the opposite of the so-called enabling behaviors (Boudrias \& Savoie, 2006) and could reflect a lack of inventive intelligence that allows employees to take initiatives that go beyond prescriptions, especially when they are deficient or contradictory (Dejours, 1998). Social entropy is the unpleasant situation in which Cameroonian workers find themselves because of the corruption of the agents and the principles which underlie informal work and which constitute with it emerging entities, originating from the chaotic functioning of the Cameroonian social system, markers of social entropy. The interpretation of entropy as a "measure of disorder" has several proponents (Carnap, 1966; Müller \& Weiss, 2005). This interpretation is not entirely irrelevant to thermodynamic entropy (Jodouin, 2015). In fact, considering the interpretation inspired by the second principle of thermodynamics according to which entropy is a measure of the loss of work (Carnot, 1824), and given the Promethean conception of work as what allows the establishment and stability of social order (Smith, 1991), it is not forbidden to establish a correspondence between high entropy and disorder. This random operation took over the administrations and companies of the national territory where it abolished all the principles of management and favored the emergence of a clandestine organization. In such an environment, employees become hired men who are exclusively inclined to sell their services to the highest bidder. When work thus becomes an opportunity to engage in a traffic that is organized around it, it becomes urgent to wonder about the opinions of real work without which the traffic it generated is no longer possible.

\section{Conceptual Framework and Assumptions}

\subsection{Conceptual Framework}

The concept of opinion was introduced into scientific research on entrepreneurship by Thurstone (1928) with his work on the measurement of attitudes. Here, the author was able to show that the measurement of attitudes is strongly correlated with that of opinions which, in his opinion, would express underlying attitudes. This is also the view of Katz (1960), who considers opinions to be a cognitive dimension of attitude and affects both the decisions, the ways in which people organize thought and the behaviour of individuals.

The survey conducted by Jaén and Linàn (2013) reveals that, some opinions encourage self-employment and intend to take active part in the process of business creation and innovation. Both authors note that, values and opinions about entrepreneurship play a very important role in the genesis of entrepreneurial intention. This idea had already been put forward by Odoardi (2005, 2008) who had noted the difficulties of accessing the measure of intention without taking into account the values and opinions of individuals. However, the authors' reflection focuses on the development of a theoretical corpus on opinions specifically related to the field of entrepreneurship. It appears that cognitions mediate the transformation of intentions into actions (Moussa Mouloun- 
gui, 2012; Nyock Ilouga, Nyock, \& Hikkerova, 2013b).

Thus one can agree with Shapero \& Sokol (1982) - that positive opinions act on desirability and feasibility which can influence the will to become an entrepreneur. According to Ajzen's (1991) proposals, a student's attitude towards starting a business would be based on his professional values and his vision of entrepreneurship. It appears that, the intention to implement an entrepreneurial project is determined by the value system and the perception that society as a whole has about the entrepreneurship (Urbano et al., 2017). Values therefore serve as a guide to human decisions and actions (Schwartz, 2006), although they may vary depending on the national context (Liñán \& Fernadez-Serrano, 2014).

Career orientation approaches emphasize values as individual variables that influence career choice and individual development. In accordance with this view, Super (1995: p. 4) states that "to fully understand an individual's career, it is necessary to explore the importance he gives to his or her roles in various activities, including work, family, recreation, education and citizenship." Therefore, the orientation towards an entrepreneurial career would be guided not only by traditional backgrounds but also by values.

Based on Ajzen's theory of planned behaviour (Ajzen, 1991, 2014) and according to which entrepreneurial behaviour is the result of the cognitive process of transforming intentions into actions, Battistelli (2006) presented a conceptual framework incorporating various proposals from existing literature to support the decisive and predictive role of opinions on career choice and entrepreneurial intent. In addition to the impact of social or environmental determinants that may influence entrepreneurial behaviour, its model of analysis also captures cognitive dispositional aspects, as do opinions and beliefs whose action regulates entrepreneurial intent. He includes opinions to which he gives the status of predictor, facilitator or inhibitor of entrepreneurial intent. From this perspective, the work of Battistelli and Nyock (2008) has shown that convergent opinions (father-mother) towards entrepreneurship influence children's career choices in favor of entrepreneurship, confirming thus the role of predictor of opinions on entrepreneurial intent. Following on from Gollwitzer's (2012) work on the Rubicon model of the phases of action, Gasse (2008) shows that a link can be made between intention, opinion and action. From this perspective, Moussa Mouloungui (2012) shows that, opinions can thus appear as mediating variables between intention and subsequent act. Although there is no deep-seated entrepreneurship, in the conceptual sense of the term, in each country, contextual specificities require alternative models that are not only possible but desirable in light of certain contingency characteristics. That is why, if we want to see actors in the informal sector transform themselves into self-employed or even entrepreneurs, it is therefore necessary to clearly identify the elements constituting the cognitive profile of the entrepreneur in their operating context deemed to be entropic.

\subsection{Problem}

The Cameroonian social context, reputed to be entropic because it flourishes the 
informal economy as well as the traffic of goods, services and principles and offers a perfect illustration of the entrepreneurial process, with the staging of the differentiated dynamics relative to environment and work (Nyock Ilouga et al., 2018). Over the past ten years, a number of entrepreneurial projects, followed and financed by the specialized structures in Cameroon, have not been transformed into businesses. According to the apparatus for generating current statistics on employment (CAMERCAP, 2015), procrastination occurs particularly at the second stage, that of action planning and concerns projects funded by the integrated support project for participants in the informal sector (PIASSI), the Rural Development Support Programme (PADER), the rural and Urban Youth Support programme (PAJER-U). For example, in 2003, 1450 Small Business development projects were funded and followed up by the integrated support project for participants in the informal sector (PIASSI). At the end of the third month after the financing, 1182 projects matured, and were actually transformed into businesses, while $268 \mathrm{did}$ not succeed. The Director of PIAASI has instructed an investigation to determine the causes of this entrepreneurial procrastination. The results revealed that the project leaders travelled to an unknown destination. Between 2005 and 2011, 9911 projects were financed by the programme and after evaluation, 1479 projects could not be turned into real businesses. In 2008, 27,624 projects for the creation of very small businesses were funded and followed up by the Rural Development Support Programme (PADER) and there were just over 18\% of entrepreneurial procrastination cases. In 2011, the Support Programme for Rural and Urban Youth (PAJER-U) funded and followed up a total of 12,750 projects for the creation of very small enterprises (VSEs) with a drop-out rate of 31.10\% (CAMERCAP, 2015). In 2016, the Centre for analysis and research on Cameroon's social policy (CAMERCAP, 2015) pointed out that $72.24 \%$ of the businesses created since 2010 are non-existent. In the same vein, 72 small and medium-sized enterprises withdrew their membership from the Cameroon Employers' Organization (GICAM) between 2014 and 2016. The results from the investigations revealed that these businesses stopped operating.

Examples of withdrawal of memberships or failures in the implementation of the entrepreneurial professional project, such as those just mentioned, are numerous in Cameroon. After the financing, some project carriers succeeded in transforming their projects into companies whose products or services occupy a share of the Cameroonian economic market, while others fail and give up. To reduce these failures, the Government of Cameroon has taken a number of measures, which revolve around the professional project, the economic context and business opportunities. With regard to the project, incubation centers have been set up in the regional headquarters, as well as structures specialized in supporting, project monitoring and evaluation (PIAASI, PAJER-U, PADER, and PIFMAS). With regard to market demand the State has assigned experts in business plan development to these structures. In addition, the technological evolution offers the possibility to connect to specialized sites, dedicated to the 
market investigation. To influence the economic context, the State has adopted a policy to encourage entrepreneurship with the creation of a bank mandate to fund business creation projects placed under the authority of the small- and medium-sized enterprises (SME) regulatory institution.

The aforementioned indicates that the measures and actions developed to stimulate and support entrepreneurship are too often oriented towards the economic context, market opportunities and the project. These actions are only very incidentally concerned with project developer himself, his opinions and motivations, his perceived and real aptitudes. That is certainly what justifies the fact that the multiplication and reinforcement of actions in favor of entrepreneurship is paradoxically accompanied by an increase in the failure rate in the implementation of certain professional integration projects. Actions that focus mainly on the economic context, market opportunities and the project are too often thwarted by the uncertainty, difficulties and risks associated with the choice of entrepreneurship as a solution for professional integration (Gelderen van, Kautonen, \& Fink, 2015). Uncertainty at first because the destructuring of the economic environment does not provide the reading clues likely to offer visibility in the short, medium or long term (Mueller, Melwani, \& Goncalo, 2012). Secondly, the difficulties in obtaining financing are insurmountable for the vast majority of project developers who cannot produce any guarantee of reimbursement and who often present themselves as free and elusive electrons in a chaotic environment (Battistelli \& Nyock, 2008; Nyock Ilouga, Nyock Mouloungui, \& Sahut, 2013a). Finally, the risks because the activity does not benefit from any protection and the competition is not framed by any regulation (Lerch et al., 2015).

\subsection{Assumptions}

In an entropic context marked by poverty, vacuity and dissipation, informal activities seem to be one of the preferred options to fight against mass unemployment and stop the progression of poverty in Africa. Odoardi's (2005) Research; Battistelli (2006) and Battistelli and Nyock (2008) help to clarify the concept of opinion and propose a specific measure to assess entrepreneurial opinions. The purpose of the present study is to continue to validate the factor structure of this scale from the situation of Cameroonian self-made men and women facing the prospect of unemployment, the scarcity of wage employment and the deterioration of working conditions. Checking the data adequacy of the factor structure of the opinion scale is the first step in our approach, which will be followed by a review of links with other related constructs such as values and Entrepreneurial intention. Assumption 1: The factor structure of the opinion scale, consisting of four sub measures, is relevant in a context dominated by informal self-employment.

In order to determine the predictive role of opinions on entrepreneurial intention, this research also seeks to empirically examine the relationships maintained by both. Assumption 2: Opinions are involved in the formulation of en- 
trepreneurial intention. While some opinions facilitate the emergence of entrepreneurial intention (benefactor, commitment and ability), others seem to have inhibitory effects (sacrifice).

\section{Methodology}

\subsection{Sample}

The questionnaire was submitted to a random sample of 2552 self-made men and women enrolled in universities and higher institutions in the central Region of Cameroon. This sample size largely meets the criteria suggested by Tabachnik and Fidell (2001) for structural equation analysis. With an average age of 19.5 years with a standard deviation of 1.84 , the first half of the sample (1482 participants in the exploratory phase) are composed mainly of girls (786) or $53 \%$ of the total sample opposed to 696 boys (47\%). Parents work in both salaried jobs and liberal professions and have been working for at least six months. In terms of training, we have $24 \%$ engineering students, $55 \%$ enrolled in ordinary fields of study (Human Sciences, Letters, Hard Sciences) and 21\% in business schools.

The process of validating the scale of opinions consisted of two complementary phases: a first phase of exploratory analysis that revealed a stable factor structure and verified the reliability of the scale. This step is followed by a confirmatory factor analysis phase to test the validity of the construct obtained in the exploratory phase. In this validation phase of the opinion scale, we conducted our analyses on the remaining 1070 individuals. With an average age of 19.6 years, this second half of the sample consists of 686 girls and 384 boys. It is not different from the first half of the sample.

\begin{tabular}{ccc}
\hline Sex & Men & Women \\
Mean age (standard deviation) & $42.32 \%$ & $57.68 \%$ \\
Ethnic groups & $19.5(5.46)$ \\
Bantus Grassfields & Percentage (\%) \\
Sudano-Sahelian & 36.84 \\
Bantus of the plain & 18.09 \\
Bantus of the forest & 24.01 \\
Field of activity & 21.05 \\
agricultural & \\
Digital Economy & 11.29 \\
Commerce & 31.43 \\
Engineering & 31.23 \\
Schooling & 26.05 \\
Engineering students & \\
Business School & 24 \\
classical courses (Human sciences, arts, life sciences) & 55 \\
\hline
\end{tabular}




\subsection{Procedure}

The research took place in two complementary phases. The objective of the first phase was to proceed with the apparent validity and content of the scales of entrepreneurial intention and opinions. In accordance with the approach developed by McGartland-Rubio et al. (2003), we formed a group of six experts made up of entrepreneurs and people who accompany project leaders in the business creation process. The experts' work was to assess the fidelity of each item to the original expression; to appreciate the clarity of the words and the level of language used to facilitate the understanding of the items and possibly propose new formulations. At the end of the in-depth examination of the observations resulting from this preliminary test of the clarity of the wordings of the items we have a tool whose presentation of the items respects the original versions. This first version of the questionnaire, which included the Entrepreneurial intention scale and the adapted version of the Opinion Scale, was pre-tested with a sample of 15 students.

The final questionnaire thus includes three main sections with a section containing personal information (age, gender, type of training). The first section focuses on entrepreneurial intention and puts the emphasis on a person's relationship with entrepreneurial activities and their commitment to completing their project ("Entrepreneurial Intention Questionnaire" (EIQ) Liñán \& Chen (2009)). It was assessed at some point in the person's life. It is therefore not fixed and can evolve positively or negatively with personal and social characteristics. Its structure consists of four dimensions built on the basis of the theory of planned behaviour: subjective norm, behavioral control, attractiveness and intention. A total of twenty items are presented to subjects that must respond by positioning themselves on a five-point Likert scale. The internal consistency of the translated scale ranges from .89 to .90 .

The second section includes the scale of opinions developed by Battistelli (2006) XE "Battistelli (2001)" and translated into French by the IDSH research team in the PSITEC laboratory at the University of Lille. It has eighteen items in four dimensions:

a) Benefactor: defines the entrepreneur as a person who contributes to the economic development of the society and promotes well-being (e.g. "entrepreneur brings economic well-being to society");

b) Commitment and Capabilities: the entrepreneur's belief as an individual with knowledge and expertise in his field and who exploits the opportunities presented to him to succeed (for example, "an entrepreneur must have many capacities to succeed");

c) Operator: The entrepreneur exploits every opportunities and people to achieve his goals (for example, "to achieve the greatest profit, the entrepreneur is willing to do anything");

d) Risks and Sacrifices: expresses the idea of a person making enormous sacrifices (example, “entrepreneur takes risks to ensure community development”). 
Participants were asked to position themselves on a Likert scale with five response choices: 1) "not agree at all," 2) "somewhat disagree," 3) "somewhat agree," 4) "agree" and 5) "strongly agree."

The third section deals with values with the "Schwartz Value Survey" (Schwartz, 2006), which brings together the ten most important values in the business. It allows to account for the perception of the values of the individual, through concepts such as autonomy, stimulation, success, power, security, conformity, tradition, benevolence, and universalism. These values are divided into four categories: personal development, openness to change, transcendence and security. They come in the form of two value lists. The first includes 30 items that describe potentially desirable goals in the form of substantives; the second includes 27 items that describe potentially desirable ways of acting in the form of adjectives. Each item expresses an aspect of the base value. Following each item, a sentence in parenthesis specifies its meaning. Interviewees highlighted the importance given to each item "as a principle of life" on a 9-point scale: (supreme importance), 6 (very important), 5, 4 (unspecified), 3 (important), 2, 1 (unspecified), 0 (unimportant), 1 (opposite to my values).

\subsection{Data Collection and Analysis Instruments}

\subsubsection{Exploratory Factor Analysis}

Using the method of unweight squares with orthogonal rotation, we extracted factors from the initial variables without looking for a prior structure. This technique minimizes residues and is appropriate when the measuring scales are ordinal. It is applicable even when the distribution of variables is not normal (Bentler, 1995). To this end, analyses were performed using version 17 of the Windows SPSS software package. The approach used consisted in:

- Retaining the number of factors that explain a significant portion of the variance;

- Selecting factors whose proper value is greater than 1 according to the Kaiser Rule (Kaiser, 1960);

- Checking the values of the Kaiser-Meyer-Olkin test (Kaiser \& Rice, 1974);

- Rotating the factors so as to improve the clarity of the factor structure: a Varimax-type orthogonal rotation that minimizes the number of items that have high contributions on an axis to simplify factors;

- Revealing the structure of the scale by removing from the measurement, statements that did not meet the following criteria:

- Correlating with a minimum of two other variables in the measurement;

- Having a factor weight greater than or equal to 0.40 with a size of no more;

- Having a standard deviation showing that the distribution of scores is sufficiently dispersed around the average.

\subsubsection{Confirmatory Factor Analysis}

Confirmatory factor analysis was carried out to test the factor structure of the questionnaire. We followed the recommendations of Anderson and Gerbing 
(1988) and of Marsh (1987) that suggest several confirmatory factor analyses to see if more parsimonious models have a better fit index. Confirmatory factor analysis is considered to be specific models of structural equations (Roussel et al., 2002).

Several indices were used to estimate the adequacy of the proposed models, i.e. the degree of correspondence between the matrix of theoretical estimates and the matrix of empirical estimates: the chi-square statistic $\left(\chi^{2}\right)$, the chi-square ratio on the corresponding number of degrees of freedom $\left(\chi^{2} / \mathrm{dl}\right)$, the Comparative Fit Index, CFI), the non-standard fit index (NNFI) proposed by Tucker and Lewis (1973), the root mean square of the estimate (RMSEA, Root Mean Square Error of Approximation by Steiger, 1990) and the modified version of the AIC (Consistent version of the AIC, CAIC) proposed by Bozdogan (1987).

The $\chi^{2}$ statistic is used to test the null hypothesis that the variances/covariance's matrix from the restrictions of the proposed model and the original model are identical. A non-significant $\chi^{2}$ therefore indicates that the proposed model provides an adequate representation of sample data (Bentler, 1995). However, it appears that a significant value of $\chi^{2}$ does not necessarily indicate that the proposed model does not adequately reproduce the sample data, as the $\chi^{2}$ statistic is very sensitive to sample size (Bentler \& Bonnett, 1980; Marsh et al., 1988). Indeed, the probability that the value of a $\chi^{2}$ is statistically significant increases with the size of the sample. On the other hand, the chi-square ratio on the corresponding number of degrees of freedom $\left(\chi^{2} / \mathrm{dl}\right)$ helps partially to correct, this problem (Hayduk, 1987). A value $\chi^{2} / \mathrm{dl}$ smaller than 5 usually means that the observed data adjusts well to the proposed theoretical model, while a value smaller than 2 corresponds to a better fit (Jöreskog \& Sörbom, 1993). Two indexes of relative adjustment were also used: CFI and NNFI. These indices vary between 0 and 1 and come from the comparison between the proposed model and the zero model (in which no link is postulated between the variables). The model with a CFI and NNFI value greater than .90 is generally considered adequate (Schumacker \& Lomax, 1996), a value greater than .95 is considered appreciable. We also used the root of the average square of the estimate (RMSEA: Root Mean Square Error of Approximation by Steiger, 1990). According to Browne and Cudeck (1993) and Marsh et al. (2005), models that offer good convergence produce an RMSEA value between .08 and .05 . On the other hand, CAIC is an important coefficient because it takes into account both the degree of adjustment of the model and the number of degrees of freedom to estimate which model seems most appropriate. The more appropriate the model, the lower the value of the CAIC (Bentler, 1995).

\section{Findings}

\subsection{The Matrix of Correlations.}

Reduced correlation matrixes subjected to exploratory factor analysis (EFAs) must have the same overall qualities as those of the original matrix. Thus, a va- 
riable that would not be correlated to any other should certainly be removed from the analysis, since we are interested in the common variance shared among the variables. Therefore, situations of moderate multi colinearity are not problematic for this type of analysis. On the other hand, it is necessary at all costs, to avoid specific situation where a variable would be fully predicted by a combination of several variables. In this case, the determinant is .027 indicating that it is not a singular matrix.

It is not advisable to proceed with an EFA if we are in the presence of an identity matrix, i.e. a matrix where all correlation coefficients would have the .0 value. Bartlett's sphericity test allows us to test the null hypothesis of a population identity matrix. The value of the chi-square obtained (2376.6; $p<.0000)$ enables to reject the null hypothesis which indicates that we are in the presence of an identity matrix. In addition, the value of KMO that is equal to .89 indicates that the variables selected are an adequate measure of opinions on entrepreneurship.

To study the links between our scale of opinion and other existing constructs, we conducted an analysis of the correlations between the dimensions of our instrument and the dimensions of the Schwartz value scale (Schwartz, 1992). This scale of Schwartz values (Schwartz, 1992) was chosen on the assumption of the conceptual link between the values of a given culture and the representations that derive from it (Sverko et al., 2008).

As the results of the second half of Table 1 show, the correlation coefficients between the dimensions of the two scales are low. On the other hand, some correlations between value scales and opinions are rather satisfactory. For example, there are links between the Benefactor dimension of the opinions scale and benevolence $(r=.66)$ and self-realization $(r=.67)$ of the value scale. The quest for social gain stimulates the individual to seek the well-being of others through

Table 1. The correlation matrix. Note: ${ }^{* *} p<.001 ;{ }^{* *} p<.01 ;{ }^{*} p<.05 ;$ ns $=$ non-significant.

\begin{tabular}{|c|c|c|c|}
\hline \multicolumn{4}{|c|}{ Opinions } \\
\hline Intention & $\begin{array}{l}\text { Entrepreneur- } \\
\text { Benefactor }\end{array}$ & $\begin{array}{l}\text { Entrepreneur-commitment } \\
\text { and capabilities }\end{array}$ & Entrepreneur-Exploiter \\
\hline Attitude & $.26^{*}$ & $-.005 \mathrm{~ns}$ & $.23^{*}$ \\
\hline Subjective standard & $.12^{\star}$ & $-.14^{\star}$ & $.12^{*}$ \\
\hline Behavioral control & $.28^{*}$ & $.00 \mathrm{~ns}$ & $.12^{*}$ \\
\hline \multicolumn{4}{|l|}{ Values } \\
\hline Power & $.29^{* * *}$ & $.11^{* * *}$ & $.96^{* * *}$ \\
\hline Universalism & $-.034 \mathrm{~ns}$ & $-.63^{\star \star}$ & $.52^{\star}$ \\
\hline Self-realization & $.67^{\star *}$ & $-.04 \mathrm{~ns}$ & $.15^{\star * *}$ \\
\hline Benevolence & $.66^{*}$ & $-.80^{\star * *}$ & $.11^{* * *}$ \\
\hline Security & $.19^{* * *}$ & $-.03 n s$ & $.14^{* * *}$ \\
\hline Stimulation & $.12 \mathrm{~ns}$ & $.72 \mathrm{~ns}$ & $.88 \mathrm{~ns}$ \\
\hline Conformity & $.88 \mathrm{~ns}$ & $-.79 \mathrm{~ns}$ & $.85 \mathrm{~ns}$ \\
\hline
\end{tabular}


personal achievements. In the meantime, relatively high integration implies a sense of being part of a community in which each individual is supposed to take responsibility for cooperating with others in the pursuit of the common interest. This finding corroborates the observations of Liñán \& Fernandez-Serrano (2014). Similarly, there is a very strong proximity between the Exploiter dimension and the need for power $(\mathrm{r}=.96)$. The prestigious social status provided by the status of entrepreneur allows to exploit, control all opportunities and all resources to achieve his/her objectives and obtain social recognition. In another vein, the Dimension commitment and Capabilities reveal negative links, not only with benevolence $(r=-.80)$, but also with universalism $(r=-.63)$. Suggesting that entrepreneurship is a necessity for informal work to be first and foremost about personal success (Nakara \& Fayolle, 2012). This last result could potentially explain the fact that the assistantship, deeply rooted in time and space, generates begging behaviors that can destroy the entrepreneurs' efforts and perseverance skills in an activity, which sometimes does not allow them to meet their needs but find themselves facing severe trials of solidarity. Therefore, if the entrepreneur wants to succeed in his activity, he must give up actions that promote collective well-being.

\subsection{Opinions and Entrepreneurial Intention}

For all participants, opinions on entrepreneurship and entrepreneurial vary significantly depending on the professional project, gender and training. The results show that the differences observed are strong and far exceed the theoretical average. Depending on the professional project, the main result is the superiority of the opinion Commitment and Capabilities among self-made men and women who wish to engage in the entrepreneurial career compared to others $(\mathrm{F}=25.53$; $p<.000)$. Students who wish to undertake risk differ significantly in the opinion of the Entrepreneur-Benefactor $(\mathrm{F}=3.27 ; p=.006)$ compared to undecided students, those who plan to continue with their studies and those who wish to get a decent job. Regarding the risk and sacrifice opinion, students who wish to create business do not integrate sacrifices into their conception of entrepreneurship or in the realization of entrepreneurial activities ( $M=4.91 \mathrm{vs} M=5.29$ for students willing to continue with their studies). This result is confirmed by the structure of the scale through factor weight analysis. On the other hand, these students think that the entrepreneur is an opportunist. From this point of view, they differ significantly from the students who are considering a dependent career $(\mathrm{M}=$ 7.55 and $M=6.75$ respectively; $p=.011$ ).

Another interesting level of analysis is about gender comparison. The sensitivity of gender responses is confirmed by the analysis of variance. Our results show that, compared to girls, boys are more likely to view the entrepreneur as an opportunist who exploits the opportunities offered by his context $(\mathrm{F}=4.70 ; p$ $<.05)$. Let's look at the difference in opinions by training. It is worth to mention that business school students are more likely to consider the entrepreneur as a 
benefactor $(\mathrm{F}=3.65 ; p=.013)$. Engineering students see the entrepreneur as a committed and competent but also as an exploitative individual ( $\mathrm{F}=2.72 ; p<$ $05)$. Students in the classical fields of studies (letters, humanities and hard sciences) essentially see sacrifices in the professions of entrepreneurship ( $\mathrm{F}=$ 3.39; $p<01$ ). Education seems to play an important role in differentiating the construction of opinions on entrepreneurship, assuming that the type of study chosen helps determine students' opinions on entrepreneurship and the entrepreneur.

In general, opinions on entrepreneurship determine the intention to undertake $(\mathrm{F}=6.44 ; p=.00)$. This result confirms the assumption that opinions are involved in the formulation of entrepreneurial intention. As we predicted the fine analysis reveals that some opinions facilitate the emergence of entrepreneurial intention while others are inhibiting. Indeed, when students perceive the entrepreneur as a benefactor $(\mathrm{F}=15.34 ; p=.00)$ and as a committed and competent individual $(\mathrm{F}=30.54 ; p=.00)$ it contributes to the emergence of entrepreneurial intention.

\section{Factor Analysis}

\subsection{The Exploratory Approach}

Examination of the factor solution shows that three items have saturations greater than 0.40 on two factors. In accordance with the hypothesis of co-linearity, we cannot decide on their dimensional assignment. So we decided to take them off the scale. The averages and standard deviations for each of the 15 initial variables selected for the opinion scale are presented in Table 2 . It indicates that 7 of the 15 items have an average of more than 3 while 8 items have an average between 2 and 3. Finally, a more detailed analysis reveals that the items in the Exploiter dimension have the lowest averages among the 15 items. Such a result is not surprising since the notion of Exploitation is not the most valued characteristic in this trade. The interpretation of this concept is not unequivocal.

It is important de observe that Cameroonian workers are forced to design their work and organize their cooperation. In this context, it seems that, for Cameroonian self-employments, the central core of the entrepreneurship processes representations is built around the notions of willing, persevering, knowledge and commitment. The second configuration contrives abilities, success and social role.

\subsection{The Structure of the Scale}

Preacher and MacCallum (2002) insist that no criteria are absolute and that the decision on the number of factors to be extracted will always involve an important element of subjectivity. They suggest combining the analysis of proper values with the study of the variance accumulation graph (Cattell, 1971) in order to make an informed decision. For this case, we will retain three factors for two reasons: 
Table 2. Descriptive statistics of items on the entrepreneurial opinion scale.

\begin{tabular}{|c|c|c|c|}
\hline ITEMS & Mean & Std. D & $\mathbf{N}$ \\
\hline 1. The entrepreneur has an important social role & 3.3084 & 1.02437 & 1482 \\
\hline 2. The entrepreneur makes contribution to community & 3.0823 & .99830 & 1482 \\
\hline 3. To be able to work independently you must have no scruples & 2.6154 & 1.21068 & 1482 \\
\hline $\begin{array}{l}\text { 4. The entrepreneur is a benefactor because he gives many people some } \\
\text { job }\end{array}$ & 2.7854 & .97773 & 1482 \\
\hline 5. To work independently, it is necessary to know his job very well & 3.9561 & .96884 & 1482 \\
\hline 6. The entrepreneur takes risks so as to ensure community development & 2.7126 & 1.04573 & 1482 \\
\hline 7. To make the greatest profit, the entrepreneur is "ready for anything" & 3.0513 & 1.25594 & 1482 \\
\hline 8. The entrepreneur brings economic well-being to his community & 2.7625 & .89049 & 1482 \\
\hline 9. The entrepreneur is willing to "exploit" the work of others & 2.6781 & 1.20585 & 1482 \\
\hline $\begin{array}{l}\text { 10. The entrepreneur is the one who puts his abilities in contribution to } \\
\text { create well-being }\end{array}$ & 2.7834 & .96020 & 1482 \\
\hline $\begin{array}{l}\text { 11. An entrepreneur must always be prepared to take advantage of any } \\
\text { situation }\end{array}$ & 3.3050 & 1.05939 & 1482 \\
\hline 12. An entrepreneur must have many abilities to succeed & 3.5850 & .99349 & 1482 \\
\hline 13. An entrepreneur must find good opportunities to succeed & 3.6032 & .90639 & 1482 \\
\hline 14. To succeed as an entrepreneur, one must be willing and persevering & 3.7416 & .95546 & 1482 \\
\hline $\begin{array}{l}\text { 15. To succeed as an entrepreneur, one has to be very committed to the } \\
\text { work }\end{array}$ & 3.5607 & .89573 & 1482 \\
\hline
\end{tabular}

The Kaiser Test (Kaiser, 1960) Requires That Only Factors with a Proper Value of 1 or More Be Considered

A closer look at the proper values chart by Cattell's elbow technique reveals a horizontal line from the third factor showing that the following factors do not provide any new information. The 3 selected factors account for $79.02 \%$ of the total variance. There is $4 \%$ of residue above 0.05 . This is a good indicator of an appropriate solution (Fornell \& Larcker, 1981).

After rotation, the factor weight matrix is much easier to analyze. A simple structure is now visible since the variables of the same name are grouped into one factor. We thus identify 3 factors as shown in Table 3 . The first factor (6 items), which corresponds to the Benefactor dimension, restores $36.68 \%$ of the common variance. The second factor (5 items) relates to the commitment and the entrepreneur's capabilities and brings together a percentage of 25.7 units of common variance. This factor also includes items such as sacrifices related to the entrepreneurial trade. The third factor ( 4 items) is interpreted as the Exploiter dimension of the entrepreneurial trade and restitutes $16.64 \%$ of the common variance.

Finally, Cronbach's alpha analysis shows that the consistency index of the opinion scale is .89 . The resulting structure was the subject of a confirmatory factor analysis. 


\subsection{Confirmatory Approach}

The scale of opinions on the entrepreneur and the entrepreneurial trade is built on the basis of three dimensions detailed in Table 3. As it can be seen from Table 4, the three-factor model is significantly better than the four-factor model.

The first model tested has a structure with a second-order dimension (entrepreneurial opinion) and three first-rate dimensions (Benefactor, Exploiter, Engagement and Capabilities). For this model, the CFI (.98) and the NNFI (.97) meet the criterion (.95) of a significant adjustment of the data. In addition, it has a value close to 3 for the index of $2 / \mathrm{dl}$ (3.19), which is considered an adequate adjustment of the data to the model. The value of the RMSEA (.06) is considered an adequate adjustment. Of the models tested, this model has the lowest value for CAIC (-102.08). In short, this model brings together the criteria for a good adjustment of empirical data to theoretical data.

Table 3. The factor structure of the opinion scale after rotation. Factor 1: Benefactor; Factor 2: Commitment and Capabilities; Factor 3: Exploiter.

\begin{tabular}{|c|c|c|c|}
\hline \multirow[b]{2}{*}{ ITEMS } & \multicolumn{3}{|c|}{ Factors } \\
\hline & 1 & 2 & 3 \\
\hline The entrepreneur brings economic well-being to his/ her community & .743 & & \\
\hline The entrepreneur contributes in the community & .742 & & \\
\hline The entrepreneur is a benefactor because he offers job to many people. & .722 & & \\
\hline $\begin{array}{l}\text { The entrepreneur is the one who puts his abilities in contribution to create } \\
\text { well-being }\end{array}$ & .711 & & \\
\hline The entrepreneur takes risks so as to ensure community development & .681 & & \\
\hline The entrepreneur has an important social role & 653 & & \\
\hline To succeed as an entrepreneur, one must be willing and persevering & & .796 & \\
\hline An entrepreneur must have many abilities to succeed & & .715 & \\
\hline An entrepreneur must find good opportunities to succeed & & .743 & \\
\hline To succeed as an entrepreneur, one has to be very committed to the work & & .613 & \\
\hline To work independently, it is necessary to know his job very well & & .537 & \\
\hline To make the greatest profit, the entrepreneur is "ready to face anything" & & & .879 \\
\hline The entrepreneur is willing to "make good use of" the work of people & & & .720 \\
\hline To be able to work independently you must have no scruples & & & .660 \\
\hline An entrepreneur must always be prepared to take advantage of any situation & & & 638 \\
\hline
\end{tabular}

Table 4. Adjustment indices obtained for each of the two models: M1 (3-factor model; and 4-factor M2 model).

\begin{tabular}{cccccccc}
\hline Models & $\chi^{2}$ & $\mathrm{dl}$ & $\chi^{2} / \mathrm{dl}$ & CFI & MNFI & CAIC & RMSEA \\
\hline Mnul & 2261.86 & 51 & & & & & \\
M1 & 332.513 & 104 & 3.19 & .98 & .97 & -102.08 & .06 \\
M2 & 347.909 & 76 & 4.57 & .69 & .63 & 81.12 & .80 \\
\hline
\end{tabular}


The second model also checks a structure with a second-order dimension. However, this model opposes the items of the commitment and Capabilities dimension against those dealing with the Risks and Sacrifices of the trade, which are ultimately autonomous factors. Adjustment indices show that this model does not provide a good representation of the data. This model does not approach the recommended value of the IFC and the NNFI. In addition, it has the greatest value at CAIC. Adjustment indices are moderate for the $\chi^{2} / \mathrm{dl}$ which is slightly less than 5 and the CAIC which has a value higher than the Model 2.

Statistically, Model 1 shows the distinction between three dimensions that assess the views that Cameroonian students, self-made men and women develop on entrepreneurship process. Nevertheless, it is interesting to assess the practical and statistical scope of this association. Why this three-dimensional model fits better statistically than the four-dimensional model when the links between the second-order dimension and the three-dimensional are greater than .73 . The answer comes from the fact that the standard error of each of the links is extremely small implying that the estimates of these links differ significantly from 1.0 by more than four or five times the value of the standard error. As a result, the links differ significantly from $1.0(p<.001)$.

\section{Discussion}

The uniqueness of Cameroon's entrepreneurial activity requires the design of adapted models to provide the theoretical and practical knowledge necessary for its development. Thus, the aim of this study is to develop and validate a measurement instrument to evaluate opinions on entrepreneurship and the entrepreneurial trade. The findings show that the model that best represents the data is a model with three sub measures in the structure. Such a model is consistent with Battistelli \& Odoardi's (2008) theory of entrepreneurial intention used as a theoretical framework.

The internal consistency for the entire scale is comparable to the original version. However, developed in a very specific socio-cultural context, the scale presents variations that may reflect the country's cultural values and norms (Jaén et al., 2017). Unlike the Battistelli model in 2001, we have a three-factor structure instead of four. The Risks and Sacrifices dimension has not been identified as a sub-measure of entrepreneurial opinions. African entrepreneurship usually begins with an informal activity and becomes a formal activity in the circumstances in which resourcefulness, the survival needs, the pursuit of prestige and the ability to trust substitute for the classic characteristics of the entrepreneur. The nature of an informal activity is to be hidden or clandestine, unstable (moves from one place to another, changes from one season to another), diversify (includes multiple trade guilds), flexible (adapts to environmental contingencies) and elusive (disappears and then reappears at the whim of the vicissitudes of the worker's life). The corruption of agents and the principles that are underpinning informal sector are all emerging entities, emerging from the chao- 
tic functioning of Cameroon's social system, markers of entropy. The result is the minimalist perception of risk. In this context, the notion of risk-taking cannot be assimilated to that of danger, uncertainty or fear of missing out on an opportunity. Opportunities that arise from economic difficulties foster entrepreneurship of necessity and even of survival. Items dealing with risk and Sacrifices, associated with the entrepreneurial trade must be interpreted with maximum caution. Thus, individuals with a high degree of skill tend to face risks as challenges to be met rather than procrastinating; refusing to make decisions and avoiding engaging in situations (Antonakis et al., 2003).

As observed by Schwartz (1992) and Jaén et al. (2017) values are universal, but there are variations from one country to another. Our findings show that in Cameroon, universalism, benevolence, power and self-realization are valued. In addition, very strong links are observed between certain dimensions of the opinion model and the dimensions of the Schwartz value scale (Schwartz, 1992). Such links between the exploiter and universalism dimensions and power which are also between the Dimensions Benefactor and Benevolence and Self-Realization, reveal the awareness of Cameroonians on the importance of promoting individual skills, creativity and independence of action at the expense of the bribery of officials and principles. It also exist between the commitment and capabilities dimension and self-improvement that offer a new vision of the social and economic environment by warning the entrepreneur against altruism by advocating selfish values favorable to development of entrepreneurial behavior. If we want to have strong and sustainable companies, it seems essential to integrate these values into any job because, as Battistelli and Odoardi (2008) point out, these dimensions represent constructive behaviors of the entrepreneur. Moreover, effective entrepreneurs generally adopt these types of values, as shown by the positive correlations obtained by Lemoine and Danvers (2010). Our results show that certain opinions about the entrepreneur (Benefactor and Commitment and Capabilities) have the power to strengthen the influence of values (openness to change and self-improvement) on entrepreneurial intention. Our study highlighted the influence of these same opinions (Benefactor and Commitment and Capabilities) on entrepreneurial intention.

From a scientific point of view, this questionnaire can help to empirically describe the variables underlying the entrepreneurial intention since the instrument has good psychometric qualities. However, further studies will be needed to further explore the predictive validity of the instrument and identify the elements relevant to the construction of the concrete representation of the trade.

In practical terms, this questionnaire can be used in determining training needs to stimulate entrepreneurship among young people.

\section{Conclusion}

With regard to the design and implementation of these persuasion measures, it seems to us that the experts involved must have some legitimacy with the reci- 
pients to facilitate communication about messages of encouragement to self-employment. Thus, it may be counterproductive to entrust persuasive actions to business plan development experts, youth and animation counselors or employment counselors. Indeed, this is contradictory, as the specialist in developing business plans is supposed to accompany the young person who wishes to undertake to elaborate the business plan. The employment counselor should use the tools mobilized to guide the young person towards self-employment or wage employment. In addition, it may be interesting to use the expertise of psychosociologists, occupational psychologists and organizations and entrepreneurship psychologists when it comes to persuading young people about the need to create business to reverse the unemployment curve.

Awareness-raising should aim to get young people to consider the entrepreneur as a benefactor, an opportunist or as a person who makes many sacrifices to contribute to the development of the community. It should also help young people to understand that the scope of an entrepreneurial ambition affects personal development more than the search for a professional activity. The personal development evoked here refers to the acquisition of values such as universalism, benevolence and self-realization. Notwithstanding the relevance of our results, we must remain cautious because they were obtained from the transverse approach. It would be interesting to check the hierarchy of volitional capacities from the longitudinal method.

\section{Conflicts of Interest}

The authors declare no conflicts of interest regarding the publication of this paper.

\section{References}

Ajzen, I. (1991). The Theory of Planned Behavior. Organizational Behavior and Human Decision Processes, 50, 179-211. https://doi.org/10.1016/0749-5978(91)90020-T

Ajzen, I. (2014). The Theory of Planned Behavior Is Alive and Well, and Not Ready to Retire: A Commentary on Sniehotta, Presseau, and Araujo-Soares. Health Psychology Review, 9, 1-7. https://doi.org/10.1080/17437199.2014.883474

Anderson, J. C., \& Gerbing, D. W. (1988). Structural Equation Modeling in Practice: A Review and Recommended Two-Step Approach. Psychological Bulletin, 103, 411-423. https://doi.org/10.1037/0033-2909.103.3.411

Antonakis, J., Avolio, B. J., \& Sivasubramniam, N. (2003). Context and Leadership: An Examination of the Nine-Factor Full-Range Leadership Theory Using the Multifactor Leadership Questionnaire. The Leadership Quarterly, 14, 261-295. https://doi.org/10.1016/S1048-9843(03)00030-4

Battistelli, A, (2001). I giovane e la scelta imprenditoriale. Milano: Angelo Guerini e associati.

Battistelli, A. (2006). The Role of Values, Belief and Motivation on Entrepreneurial Intention. Athens, Greece: ICAP-26th International Congress of Applied Psychology.

Battistelli, A., \& Nyock, I.S. (2008). Le rôle du soutien familial dans la prédiction de l'intention entrepreneuriale. Quebec, Canada: Congrès de l'Association Internationale 
de Psychologie du Travail de Langue Française.

Battistelli, A., \& Odoardi, C. (2008). La psicologia dell'imprenditorialità. In D. P. Argentero, \& C. Cortese (Eds.), Psicologia del lavoro. Milano: Rafaello Contina Editore.

Bentler, P. M. (1995). EQS Structural Equations Program Manual. Encino, CA: Multivariate Software.

Bentler, P. M., \& Bonnett, D. G. (1980). Significance Tests and Goodness-of-Fit in TNE Analysis of Covariance Structures. Psychological Bulletin, 88, 588-606. https://doi.org/10.1037/0033-2909.88.3.588

Boudrias, J. S., \& Savoie, A. (2006). Les manifestations comportementales de l'habilitation au travail: Développement d'un cadre conceptuel et d'un instrument de mesure. Psychologie du Travail et des Organisations, 12, 119-138. [The Behavioral Manifestations of Work Empowerment: Framework and Tools. Organization and Work Psychology, 12, 119-138]. https://doi.org/10.1016/j.pto.2006.03.005

Bozdogan, H. (1987). Model Selection and Akaike's Information Criteria (AIC): The General Theory and Its Analytical Extensions. Psychometrika, 52, 345-370. https://doi.org/10.1007/BF02294361

Browne, M. W., \& Cudeck, R. (1993). Alternative Ways of Assessing Modelfit. In D. K. A. Bollen, \& J. S. Long (Eds.), Testing Structural Model (pp. 1993). Newbury: Sage Publication.

CAMERCAP (2015). Suivi de la démographie des petites et moyennes entreprises au Cameroun.

Carnap, R. (1966). Philosophical Foundations of Physics. New York: Basic Books.

Carnot, S. (1824). Réflexion sur la puissance motrice du feu et les machines propres à développer cette puissance. [Reflection on the Motive Power of Fire and the Machines Fit to Develop This Power] Paris: Gauthier-Villard (Bachelier).

Cattell, R. B. (1971). Abilities, Their Structure, Growth and Action. Boston: Houghton Miflin.

Dejours, C. (1998). Souffrance en France. [Suffering in France] Paris: Seuil.

Fornell, C., \& Larcker, F. (1981). Evaluating Structural Equation Model with Unobservables Variables and Measurement Error. Journal of Marketing Research, 18, 39-50. https://doi.org/10.1177/002224378101800104

Gasse, Y. (2008). Conditions et influences majeurs dans l'intention entrepreneurial. Dans N. Pettersen, J. B. Boudrias, \& A. Savoie (Eds.), Entre tradition et innovation, comment transformons-nous l'univers du travail? Québec: Presses de l'Université de Québec.

Gelderen van, M., Kautonen, T., \& Fink, M. (2015). From Entrepreneurial Intentions to Actions: Self-Control and Action-Related Doubt, Fear, and Aversion. Journal of Business Venturing, 30, 655-673. https://doi.org/10.1016/j.jbusvent.2015.01.003

Gollwitzer, P. M. (2012). Mindset Theory of Action Phases. D. P. Van Lange, A. W. Kruglanski, \& E. T. Higgins (Eds.), Handbook of Theories of Social Psychology (Vol. 1, pp. 526-545). London: Sage Publication. https://doi.org/10.4135/9781446249215.n26

Hayduk, L. A. (1987). Structural Equation Modeling with LISREL: Essentials and Advances. Baltimore, MD: Johns Hopkins.

Jaén, I., \& Linàn, F. (2013). Work Values in a Changing Economic Environment: The Role of Entrepreneurial Capital. International Journal of Manpower, 34, 939-960. https://doi.org/10.1108/IJM-07-2013-0166

Jaén, I., Fernandez-Serrano, J., Santos, F. J., \& Linàn, F. (2017). Cultural Values and Social Entrepreneurship: A Cross-Country Efficiency Analysis. International Studies in Entrepreneurship, 36, 31-51. https://doi.org/10.1007/978-3-319-50850-4_3 
Jodouin, L. (2015). Emergence et entropie: une analyse critique des stratégie emergentistes basées sur le concept d'entropie. [Emergence and Entropy: A Critical Analysis] Paris: Université Panthéon-Sorbonne.

Jöreskog, K. G., \& Sörbom, D. (1993). LISREL 8: User's Reference Guide. Chicago, IL: Scientific Software.

Kaiser, H. F. (1960). The Application of Electronic Computers to Factor Analysis. Educational and Psychological Measurement, 20, 141-151. https://doi.org/10.1177/001316446002000116

Kaiser, H. F., \& Rice, J. (1974). Little Jiffy, Mark IV. Educational and Psychological Measurement, 34, 111-117. https://doi.org/10.1177/001316447403400115

Katz, D. (1960). The Functional Approach to Study Attitudes. Public Opinion Quarterly, 24, 163-204. https://doi.org/10.1086/266945

Krueger, N. F., \& Carsrud, A. I. (1993). Entrepreneurial Intention: Applying the Theory of Planned Behavior. Entrepreneurship \& Regional Development, 5, 315-330. https://doi.org/10.1080/08985629300000020

Lemoine, C., \& Danvers, F. (2010). Représentations, Valeurs et compétences préparent à la création d'entreprise. Transformations, 3, 201-214.

Lerch, C., Thi Thanh Thai, M., Puhakka, V., \& Burger-Helmchen, T. (2015). La réactivité entrepreneuriale: le sens pratique pour concrétiser les idées originales. Innovations, 3, 5-11. https://doi.org/10.3917/inno.048.0005

Liñán, F., \& Chen, Y. W. (2009). Development and Cross-Cultural Application of a Specific Instrument to Measure Entrepreneurial Intentions. Entrepreneurship Theory and Practice, 33, 595-617. https://doi.org/10.1111/j.1540-6520.2009.00318.x

Liñán, F., \& Fernadez-Serrano, J. (2014). National Culture, Entrepreneurship and Economic Development: Different Patterns across the European. Small Business Economics, 42, 685-701. https://doi.org/10.1007/s11187-013-9520-x

Marsh, H. W. (1987). The Hierarchical Structure of Self-Concept and the Application of Hierarchical Confirmatory Factor Analysis. Journal of Educational Measurement, 24, 17-39. https://doi.org/10.1111/j.1745-3984.1987.tb00259.x

Marsh, H. W., Balla, J. R., \& McDonald, R. P. (1988). Goodness-of-Fit Indexes in Confirmatory Factor Analysis: The Effect of Sample Size. Psychological Bulletin, 103, 391-411. https://doi.org/10.1037/0033-2909.103.3.391

Marsh, H. W., Ellis, L. A., Parada, R. H., Richards, G., \& Heubeck, B. G. (2005). A Short Version of Self Description Questionnaire II: Operationalizing. Psychological Assessment, 17, 81-102. https://doi.org/10.1037/1040-3590.17.1.81

McGartland-Rubio, D., Berg-Weger, M., Tebb, S. S., Lee, S. E., \& Rauch, S. (2003). Objectifying Content Validity: Conducting a Content Validity in Social Work Research. Social Research, 27, 94-104. https://doi.org/10.1093/swr/27.2.94

Mercure, D., \& Vultur, M. (2010). La signification du travail: Nouveau modele productif et ethos du travail au Québec. Québec: Presse de l'Université Laval. [The Meaning of Work: The New Framework. Quebec: Laval University Press].

Moussa Mouloungui, A. C. (2012). Processus de transformation des intentions en actions entrepreneuriales. Thèse de doctorat, Villeneuve d'Ascq and Vérone: Université Lille 3; Université de Vérone.

Mueller, J., Melwani, S., \& Goncalo, J. (2012). The Bias Against Creativity: Why People Desire But Reject Creative Ideas. Psychological Science, 23, 13-17.

https://doi.org/10.1177/0956797611421018

Müller, I., \& Weiss, W. (2005). Entropy and Energy. An Universal Competition. Heidel- 
berg: Springer Verlag.

Nakara, W. A., \& Fayolle, A. (2012). Les bad pratiques d'accompagnement à la création d'entreprie: Le cas des entrepreneurs par nécessité. Revue Française de Gestion, 9-10, 231-251. https://doi.org/10.3166/rfg.228-229.231-251

Nyock Ilouga, S., Moussa Mouloungui, A. C., Arnoux-Nicolas, C., \& Bernaud, J. L. (2018). Do the Meaning of Work and the Coherence between a Person and His Work Environment Express the Same Reality? Psychology, 9, 2175-2193.

https://doi.org/10.4236/psych.2018.98124

Nyock Ilouga, S., Nyock Mouloungui, A. C., \& Sahut, J. M. (2013a). Entrepreneurial Intention and Career Choices: The Role of Volition. Small Business Economics, 42, 717-728. https://doi.org/10.1007/s11187-013-9524-6

Nyock Ilouga, S., Nyock, A. C., \& Hikkerova, L. (2013b). Influences des perceptions sociales sur l'intention entrepreneuriale. Gestion, 31, 115-130. https://doi.org/10.3917/g2000.305.0115

Odoardi, C. (2005). Le röle des opinions et de la motivation ur les intentions entrepreneuriales. In D. A. Battistelli, M. Depolo, \& F. Fraccaroli (Eds.), La qualité de vie au travail dans les années 2000 (pp. 751-759). Bologna: Actes du XIII Congrès de l'AIPTLF, CLUEB, CD-R.

Odoardi, C. (2008). Le rôle des valeurs, opinions et motivation sur l'intention entrepreneuriale. Paris: L'Harmattan.

Peris-Ortiz, M., Teulon, F., \& Bonet-Fernandez, D. (2017). Social Entrepreneurship in Non-Profit and Profit Sectors: Theorical and Empirical Perspectives. International Studies in Entrepreneurship, 36. https://doi.org/10.1007/978-3-319-50850-4_1

Preacher, K. J., \& MacCallum, R. C. (2002). Exploratory Factor Analysis in Behavior Genetics Research: Factor Recovery with Small Sample Sizes. Behavior Genetics, 32, 153-161. https://doi.org/10.1023/A:1015210025234

Roussel, P., Durrieu, F., Campoy, E., \& El Akremi, A. (2002). Méthodes d'équations structurelles: Recherche et applications en gestion. Economica.

Schumacker, R. E., \& Lomax, R. G. (1996). A Beginner's Guide to Structural Equation Modeling. NJ Mahwah: Lawrence Erlbaum Associates.

Schwartz, S. H. (1992). Universals in the Content and Structure of Values: Theory and Empirical Tests in 20 Countries. In D. M. Zanna (Ed.), Advances in Experimental Social Psychology (Vol. 25, pp. 1-65). New York: Academic Press. https://doi.org/10.1016/S0065-2601(08)60281-6

Schwartz, S. H. (2006). Les valeurs de base de la personne: Théorie, mesures et applications [Basic Human Values: Theory, Measurement, and Applications]. Revue Française de Sociologie, 47, 249-288. https://doi.org/10.3917/rfs.474.0929

Shapero, A., \& Sokol, L. (1982). The Social Dimensions of Entrepreneurship. In D. C. A. Kent, D. L. Sexton, \& K. H. Vesper (Eds.), Encyclopedia of entrepreneurship (pp. 72-90). Prentice-Hall, NJ: Englewood Cliffs.

Smith, A. (1991). Recherches sur la nature et les causes de la richesse des nations. Paris: GF.

Steiger, J. H. (1990). Structural Model Evaluation and Modification: An Interval Estimation Approach. Multivariate Behavioral Research, 25, 173-180. https://doi.org/10.1207/s15327906mbr2502_4

Super, D. E., \& Sverko, B. (1995). Life Roles, Values and Careers. International Findings of the Work Importance Study. San Francisco, CA: Jossey-Bass.

Sverko, B., Babarovic, T., \& Sverko, I. (2008). Assessment of Values and Role of Salience. 
San Francisco, CA: Jossey-Bass. https://doi.org/10.1007/978-1-4020-6230-8_27

Tabachnik, B. G., \& Fidell, L. S. (2001). Using Multivariate Statistics (4th ed.). Boston, MA: Allyn and Bacon.

Thurstone, L. L. (1928). Attitudes Can Be Measure. American Journal of Sociology, 33, 529-554. https://doi.org/10.1086/214483

Tucker, L. R., \& Lewis, C. (1973). A Reliability Coefficient for Maximum Likelihood Factor Analysis. Psychometrika, 38, 1-10. https://doi.org/10.1007/BF02291170

Urbano, D., Ferri, E., Peris-Ortiz, M., \& Aparicio, S. (2017). Social Entrepreneurship and Institutional Factors: Literature Review. International Studies in Entrepreneurship, 36, 18-33. https://doi.org/10.1007/978-3-319-50850-4_2 